\title{
Quality of sausage elaborated using minced Nile Tilapia submmitted to cold storage
}

\author{
Paulo Roberto Campagnoli de Oliveira Filho; Carmen Sílvia Fávaro-Trindade²; Marco \\ Antônio Trindade²; Júlio Cesar de Carvalho Balieiro ${ }^{3}$; Elisabete Maria Macedo Viegas ${ }^{1,4^{*}}$ \\ ${ }^{1}$ CAUNESP - Programa de Pós-Graduação em Aquicultura, Via de Acesso Prof. Paulo Donato Castellane, s/n. - \\ 14884-900 - Jaboticabal, SP - Brasil. \\ ${ }^{2} U S P / F Z E A$ - Depto. de Engenharia de Alimentos. \\ ${ }^{3}$ USP/FZEA - Depto. de Ciências Básicas. \\ ${ }^{4}$ USP/FZEA - Depto. de Zootecnia, Av. Duque de Caxias Norte, 225 - C.P. 23 - 13635-900 - Pirassununga, SP - Brasil. \\ *Corresponding author <emviegas@usp.br>
}

\begin{abstract}
Filleting yield of Nile tilapia Oreochromis niloticus (L.) is low (30\%) and generates large amount of wastes that may turn into environmental and economic problem. However, these wastes can be used for the extraction of minced fish (MF) which can be used in the preparation of sausages. The objective of this study was to assess the quality of sausages prepared with 0,20,40,60, 80 and 100\% of MF from Nile tilapia filleting waste during storage at $0 \pm 0.3^{\circ} \mathrm{C}$. Alterations in the instrumental color $\left(\mathrm{L}^{*}, \mathrm{a}^{*}\right.$ and $\left.\mathrm{b} *\right)$, lipid oxidation (TBARS), total volatile nitrogenous bases (TVB-N), pH, microbiological condition (pathogenic bacteria and aerobic psychrotrophic bacteria), and sensory attributes (color, odor, flavor, texture and overall acceptability) were evaluated for up to 40 days. The addition of MF to sausages increased TBARS values and decreases TVB$\mathrm{N}, \mathrm{L}^{*}, \mathrm{a}^{*}$ and $\mathrm{b}$ * values. Acceptability of color attribute decreased with increasing MF; best flavor, texture and overall acceptability scores were registered for sausages containing 40 and $60 \%$ MF; best odor was registered for $100 \%$ MF. Pathogenic microorganisms were not detected, but decrease in $\mathrm{pH}$ and proliferation of aerobic psychrotrophic bacteria which, however, did not compromise sensory evaluation of sausages were registered throughout storage. Sausages prepared with MF from tilapia filleting waste have a shelf-life of 40 days when stored at $0 \pm 0.3^{\circ} \mathrm{C}$, and the maximum recommended $\mathrm{MF}$ inclusion to maintain good sensory quality is $60 \%$. Key words: Fish sausage, lipid oxidation, filleting waste, shelf-life, sensory acceptability
\end{abstract}

\section{Qualidade de salsichas elaboradas com carne mecanicamente separada de tilápias do Nilo e armazenadas sob refrigeração}

\begin{abstract}
RESUMO: O rendimento de filetagem da tilápia do Nilo, Oreochromis niloticus, Linnaeus, é considerado baixo (30\%) gerando conseqüentemente uma grande quantidade de resíduos que podem causar perdas econômicas e problemas ambientais. Estes resíduos podem ser utilizados para a obtenção de carne mecanicamente separada (CMS) e utilizado na elaboração de salsichas. Avaliou-se a qualidade de salsichas elaboradas com 0, 20, 40, 60, 80 e $100 \%$ de inclusão de CMS de resíduos de filetagem de tilápias do Nilo armazenadas a $0 \pm 0,3^{\circ} \mathrm{C}$. As alterações de cor instrumental ( $\mathrm{L}^{*}, \mathrm{a}^{*} \mathrm{e} \mathrm{b}$ ), oxidação lipídica (TBARS), bases nitrogenadas voláteis totais (TVB-N), pH, microbiológicas (bactérias patogênicas e aeróbias psicrotróficas) e sensoriais (cor, odor, sabor, textura e aceitação global) foram avaliadas por até 40 dias. A adição de CMS em salsichas causou aumento nos valores de TBARS e diminuição nos valores de BNV, $\mathrm{L}^{*}$, $\mathrm{a}^{*} \mathrm{e} \mathrm{b}$. A aceitação do atributo cor diminuiu com o incremento de CMS. O melhor sabor, textura e aceitação global foram obtidos em salsichas que continham 40 e $60 \%$ de CMS, e o odor com $100 \%$ de CMS. Não foi detectada presença de bactérias patogênicas. Durante o período de estocagem houve diminuição no $\mathrm{pH}$ e multiplicação das bactérias aeróbias psicrotróficas, porém não comprometendo na avaliação sensorial das salsichas. Portanto, salsichas elaboradas com CMS de resíduos de filetagem de tilápia apresentam vida de prateleira de 40 dias, quando estocadas a $0 \pm 0,3^{\circ} \mathrm{C}$, e o máximo de inclusão de $\mathrm{CMS}$ recomendado, mantendo a boa qualidade sensorial, é de 60\%.

Palavras-chave: Salsicha de pescado, oxidação lipídica, resíduos de filetagem, vida de prateleira, aceitação sensorial
\end{abstract}

\section{Introduction}

Nile tilapia, Oreochromis niloticus (L.) is a tropical fish with good growth rate rusticity, tasty, white-color meat devoid of "Y"-shaped, intramuscular bones. However, the species' filleting yield (30 to $35 \%$ ) is considered low (Garduño-Lugo et al., 2003), generating large amounts of waste that may turn into environmental and economic problems. However, these wastes can also be used for the extraction of minced fish (MF) (Kristbergsson and Arason, 2007) or fish meal (Szenttamásy et al., 1993); MF can be used as a raw material for the preparation of various types of fisheries products, sausages included (Daley et al., 1979; Hu et al., 2008; Park et al., 1978).

To obtain MF, flesh muscle is ruptured increasing the tissue surface exposed to temperature, favoring lipid 
oxidation (Kelleher et al., 1992) and contamination by microorganisms (Tenuta-Filho and Jesus, 2003). In addition, blood pigments can spread to and darken minced mass, hampering the use of large proportions of MF in meat products for it may cause color, odor, texture and flavor alterations (Trindade et al., 2005). Thus, evaluating the inclusion of MF and the shelf-life of products prepared with this raw material becomes important. Sini et al. (2008), for instance, studied the shelf-life of sausages produced with MF from rohu, Labeo rohita, and reported that preparing sausages from rohu's MF is feasible, given the good physicochemical characteristics and shelf-life of up to 16 days when that raw material is stored at $5^{\circ} \mathrm{C}$. Although fish meat is known to be of good nutritional quality and sausages are widely consumed, there only a few studies evaluate the development and shelf-life of sausages produced with MF.

The objective of this study was to assess the quality of sausages prepared with inclusion levels of $\operatorname{MF}(0,20$, $40,60,80$ and $100 \%$ ) from Nile tilapia filleting waste in substitution of the fillet, and evaluate its physicochemical, microbiological and sensory alterations when stored at $0 \pm 0.3^{\circ} \mathrm{C}$ for a period of up to 40 days.

\section{Material and Methods}

Nile tilapia filleting wastes $(150 \mathrm{~kg})$ - headless vertebral column spines, skin and viscera - were supplied frozen by a filleting company and transported insulated boxes to the laboratory. Approximately $24 \mathrm{~h}$ before processing, wastes were thawed, washed, trimmed to remove excess fat and passed through an industrial fish deboning machine, yielding 53\% MF - $75.47 \pm 0.18 \%$ moisture, $12.76 \pm 0.61 \%$ protein, $10.54 \pm 0.66 \%$ lipids, $1.14 \pm 0.17 \%$ ash - which was packed into 500 -g plastic bags and quick frozen (ultra-rapid plate freezer; $-40^{\circ} \mathrm{C}$ ). Tilapia fillets $(40 \mathrm{~kg})-78.85 \pm 2.69 \%$ moisture, $18.74 \pm$ $1.09 \%$ protein, $1.28 \pm 0.89 \%$ lipids, $1.05 \pm 0.13 \%$ ash were acquired from a packing plant.

Sausages formulations and processing: formulations were designed to produce $12 \mathrm{~kg}$ of sausage, substituting tilapia fillet by $0,20,40,60,80$ and 100\% MF. Remaining formulations' ingredients had the same proportions: $4 \%$ isolated soy protein, $2 \%$ cassava starch, $1 \%$ salt, $0.25 \%$ curing salt, $0.5 \%$ antioxidant, $0.25 \%$ stabilizer, $1 \%$ sausage seasoning, and $2 \%$ natural onion. The raw materials (MF and fillet) were thawed for $24 \mathrm{~h}$, weighed, comminuted and emulsified in the cutter with the other ingredients for $5 \mathrm{~min}$. The temperature of emulsified mass at the cutter output was $1^{\circ} \mathrm{C}$. Emulsions were then filled (pneumatic sausage filler) into commercial, 25-mm cellulose casing, hand tied and cooked in an oven under direct steam until internal temperature reached $72^{\circ} \mathrm{C}$ (i.e. 1h20) (Uyhara et al., 2008). Sausages were then cooled (cold water spray) until the internal temperature droped to $40^{\circ} \mathrm{C}$. After manual removal of casings, sausages were vacuum packaged in $15 \mathrm{X} 35 \mathrm{X} 0.018 \mathrm{~mm}$ polyamide/polyethylene bags, mean barrier to oxygen and water vapor, (Selovac, São Paulo, SP) and stored un- der refrigeration $\left(0 \pm 0.3^{\circ} \mathrm{C}\right)$ until analyzed. Analysis were done triplicate six sausages packs $(240 \mathrm{~g})$ pre-homogenized in a food processor, at 5, 12, 19, 26, 33 and 40 days of storage.

Lipid oxidation was determined using the thiobarbituric acid reactive substances method (TBARS) (Vyncke, 1970). Homogenate sub-samples (5 g) were mixed with $25 \mathrm{~mL}$ of trichloroacetic acid solution $(7.5 \%$ TCA, $0.1 \%$ EDTA and $0.1 \%$ propyl gallate), homogenized for $1 \mathrm{~min}$ and filtered through filter paper. In a test tube, $4 \mathrm{~mL}$ of the filtrate were mixed with $1 \mathrm{~mL}$ of $7.5 \%$ TCA solution and $5 \mathrm{~mL}$ of $0.02 \mathrm{M}$ TBARS solution. Tubes were boiled in a water bath for $40 \mathrm{~min}$, cooled under running water and taken to optical density (OD) reading in spectrophotometer at $538 \mathrm{~nm}$. TBARS values were calculated against a standard curve $(\mathrm{y}=54.134 \times+0.0008)$ obtained with tetramethoxypropane and results expressed as $\mathrm{mg}$ malonaldehyde $\mathrm{kg}^{-1}$ sample.

For determination of total volatile nitrogenous bases (TVB-N; Howgate, 1976), approximately $10 \mathrm{~g}$ of homogenate were sampled and homogenized with $60 \mathrm{~mL}$ of 10\% TCA solution for $1 \mathrm{~min}$ and set to rest for $2 \mathrm{~h}$. The sample was then filtered through filter paper; $25 \mathrm{~mL}$ of the filtrate $+1 \mathrm{~g}$ of magnesium oxide were transfered to a flask and fitted into the nitrogen distillation apparatus, where the contents were distilled with $15 \mathrm{~mL}$ of methyl red plus bromocresol green mixed indicator and titrated with $0.02 \mathrm{~N} \mathrm{HCL}$. The values were expressed as $\mathrm{mg} 100 \mathrm{~g}^{-1}$. The instrumental color was determined with the aid of a portable colorimeter previously calibrated with black and white standards before each analysis, operating with a D65 light source, observation angle of $10^{\circ}$ and $30 \mathrm{~mm}$ opening of the measuring cell (Garcia et al., 2000). The color was expressed using the CIELab system color standard - "Commission Internationale de L'Eclairage": L* (lightness), a* (red-green color intensity) and $\mathrm{b}^{*}$ (yellow-blue color intensity). The $\mathrm{pH}$ was measured in a pHmeter with the electrode immersed in a mixture of $10 \mathrm{~g}$ of sample plus $40 \mathrm{~mL}$ of distilled water.

Microbiological tests were performed according to APHA (1992). The presence of total coliforms, Salmonella spp., Staphylococcus aureus and the aerobic psychrotrophic count were determined in the sausages at 5 or 40 days of storage. For the determination of aerobic psychrotrophic microorganisms, $0.1 \mathrm{~mL}$ of a $10^{-1} \mathrm{di}-$ lution was added to a Petri dish containing PCA agar. Plates were then inverted and incubated at $7 \pm 0.3^{\circ} \mathrm{C}$ for ten days and results were expressed in CFU (colonyforming units) per gram of sample. To determine the population of total coliforms, $1 \mathrm{~mL}$ of the $10^{-1}$ dilution was transferred to each of three test tubes containing 10 $\mathrm{mL}$ of lauryl sulphate broth and an inverted Duran tube. The tubes were incubated at $35 \pm 0.3^{\circ} \mathrm{C}$ for $48 \mathrm{~h}$ and the most probable number (MPN) was determined with the aid of a specific table in the case of positive tubes, i.e., those with the presence of gas. The rapid method was used in the analysis of Salmonella spp. after a pre-enrich- 
ment and for the analysis of Staphylococcus aureus, 0.1 $\mathrm{mL}$ of a $10^{-1}$ dilution was added to a Petri dish containing Baird-Parker agar enriched with egg yolk emulsion. The inoculum was spread over the agar surface, and the plates inverted and incubated at $35 \pm 0.3^{\circ} \mathrm{C}$ for $24 \mathrm{~h}$.

The sensory evaluation of the sausages was carried in individual booths with white fluorescent light. In accordance with Resolution 196/96 of the Brazilian Ministry of Health, this study was approved by the Committee of Ethics in Research (FMRP-USP, under protocol number 0190/2006). The affective acceptability tests were performed using methodology described by Meilgaard et al. (1999) at 5, 19, 33 and 40 days of storage. Samples were evaluated using a 9-point hedonic scale (1 - "disliked extremely" to 9 - "liked a lot") for the attributes flavor, texture, color, odor and overall acceptability. Sixty untrained panelists of both sexes and age groups participated in the acceptability test. All panelists presented the habit of regular consumption of fisheries products. Sausage samples were presented to the panelists in a monadic way under a completely randomized blocks experimental design, panelists representing blocks. Sausages were heated for $5 \mathrm{~min}$ in boiling water, cut into $2 \mathrm{~cm}$-long pieces and kept in a warm oven (approximately $40^{\circ} \mathrm{C}$ ) and served to the panelists in disposable plastic containers, along with water and cream crackers. Trials were set up in a completely randomized experimental design with two factors and cross classification. The factor $\operatorname{MF}(0,20,40,60,80$ and $100 \%$ of MF) and factor Storage $(5,12,19,26,33$ and 40 days) were arrangement in a $6 \times 6$ factorial scheme $(n=2)$. Data were analyzed using ANOVA; a regression analysis and Pearson's correlation coefficients were applied whenever differences were found $(p=0.05)$. All statistical tests were performed using SAS (2002) statistical software, version 9.1.3.

\section{Results and Discussion}

The ANOVA for TBARS detected only principal effects for Storage and MF. Despite the differences detected with time for the TBARS values during storage $(p<0.05)$, no trend of values could explained by a simple regression model up to the 3 rd degree. TBARS values ranged on 0.75 to $1.08 \mathrm{mg} \mathrm{kg}^{-1}$. However, an increase in the TBARS values during storage at 2 to $4{ }^{\circ} \mathrm{C}$ was observed in other studies with sausages containing MF (Daley et al., 1979; Park et al., 1978; Panpipat and Yongsawatdigul, 2008).

Sausages differed $(p<0.05)$ regarding TBARS values (Figure 1). TBARS values increased, from $0.67 \mathrm{mg}$ $\mathrm{kg}^{-1}$ (no MF added) to $1.24 \mathrm{mg} \mathrm{kg}^{-1}(100 \% \mathrm{MF})$ with increasing MF percentage in the sausages. The lower TBARS values recorded for sausages with less MF seemingly resulted from the lower lipids contents in these sausages, since the tilapia fillet raw material used in the formulation had fewer lipids than MF (1.28 and 10.54\% of lipids, respectively). Lipid oxidation of sausages may be related to the quantity of lipids and fatty acids present

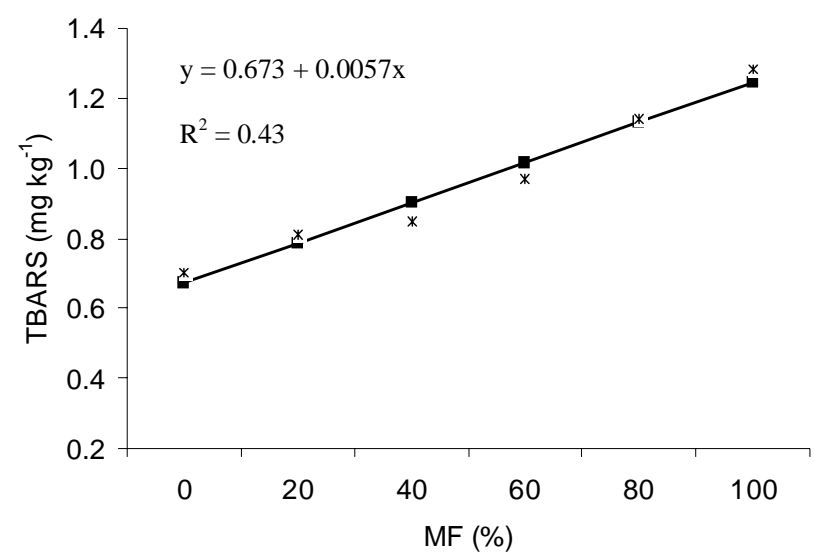

Figure 1 - Values of thiobarbituric acid reactive substances (TBARS) in sausages prepared with inclusion levels of minced fish (MF) from Nile tilapia filleting waste and stored for 40 days at $0 \pm 0.3^{\circ} \mathrm{C}$.

in the products (Murphy et al., 2004). Furthermore, the process of obtaining MF can cause disruption of muscle membranes, facilitating interaction of the oxidizing agents with polyunsaturated fatty acids, resulting in the propagation of oxidative reactions (Estévez et al., 2007; Gray et al., 1996). Trindade et al. (2005) also registered increased TBARS values, from 0.15 to $0.56 \mathrm{mg} \mathrm{kg}^{-1}$, with increasing percent inclusion of mechanically separated layer hen meat in mortadella sausage. Brazilian legislation does not indicate a limit for lipid oxidation as measured by the TBARS for fisheries products; however, oxidized foods are more prone to the formation of toxic compounds such as aldehydes, ketones, alcohols, acids and hydrocarbons (Summo et al., 2006).

TVB-N values of the sausages did not vary $(p>0.05)$ during the 40-day storage, probably as a result of the good storage conditions. In contrast, López-Caballero et al. (2005), Ravishankar et al. (1992), Raju et al. (2003) and Sini et al. (2008) reported increased TVB-N values for sausages prepared with MF from cod, Gadus sp., sardine, Sardinella longiceps, Japanese threadfin bream, Nemipterus japonicus, and rohu, Labeo Robita, after 25, 26,30 and 13 days storage at $2,6,2$ and $5^{\circ} \mathrm{C}$, respectively, and related this increase in the TVB-N values to the development of enzymatic and microbial activity in products developed with MF.

TVB-N values decreased linearly $(p<0.05)$ with increasing MF contents in the sausages, from $13.68 \mathrm{mg} 100$ $\mathrm{g}^{-1}$ (no MF added) to $8.24 \mathrm{mg} 100 \mathrm{~g}^{-1}$ (100\% of MF) (Figure 2). This reduction in the TVB-N values with the increasing MF contents can be explained either by the lower amount of protein in the sausages prepared with larger amounts of MF, although no reports corroborating this statement could be found in the literature, or by the better quality of the filleting waste in relation to the tilapia fillet used in the experiment.

TVB-N is built up by ammonia, trimethylamine and dimethylamine originated from the breakdown of nucleotides and from the deamination of amino acids by microorganisms (Contreras-Guzmán, 2002). Therefore, the 
higher the percentage of protein (amino acids) in a given product, the greater the possibility of high TVB-N values for the product. The Brazilian legislation (Brasil, 2000) establishes that fresh fish intended for human consumption must present a maximum of $30 \mathrm{mg} 100 \mathrm{~g}^{-1}$ of TVB-N, and thus TVB-N values for all treatments remained within acceptable limits, i.e., $<13.68 \mathrm{mg} 100 \mathrm{~g}^{-1}$.

$L^{*}, a^{*}$ and $b^{*}$ values during the 40-day storage did not differ $(p>0.05)$, meaning that sausages were processed and stored under good conditions, since factors such as MF processing and excessive incidence of light and oxygen during storage result in lipid and pigment oxidation, causing changes in product color (Olivo, 2006). López-Caballero et al. (2005) also observed no changes in the $L^{*}$ and $b *$ values in sausages containing $\mathrm{MF}$ from cod after 25 days of storage at $2^{\circ} \mathrm{C}$. However, the $L^{*}, a^{*}$ and $b^{*}$ values of the sausages decreased $(p<$ $0.05)$ with increasing MF contents (Figure 3 ). The $L^{*}$ values of sausages decreased linearly $(p<0.05)$ with increasing MF: 68.1 for no MF added to 65.13 for $100 \%$ MF (Figure 3a). This phenomenon can be explained by the darker color of MF in comparison to tilapia fillet. The $\mathrm{a}^{*}$ values of the sausages showed a quadratic decrease $(p<0.05)$ with increasing MF inclusion, from 2.95 (no MF added) to 2.25 (100\% MF) (Figure 3b). This phenomenon may have occurred because the MF shows little red color, presenting a more grayish color (visual assessment) as a result of the presence of fins in the filleting waste. Other authors also found a reduction in the $a^{*}$ values with the addition of bovine-heart surimi in sausages (Desmond and Kenny, 1998) and of mechanically separated layer hen meat in mortadella sausage (Trindade et al., 2005). The $b *$ values of the sausages decreased in a quadratic trend $(p<0.05)$ with increasing inclusion of MF, from 16.55 (no MF added) to 11.45 (100\% MF) (Figure 3c). Sausages produced with lower percentages of MF showed a more yellowish color, probably as a result of the neutral color of the fillets, enabling the expression of the color of the non-meat ingredient added in higher percentage, i.e. isolated soy protein,

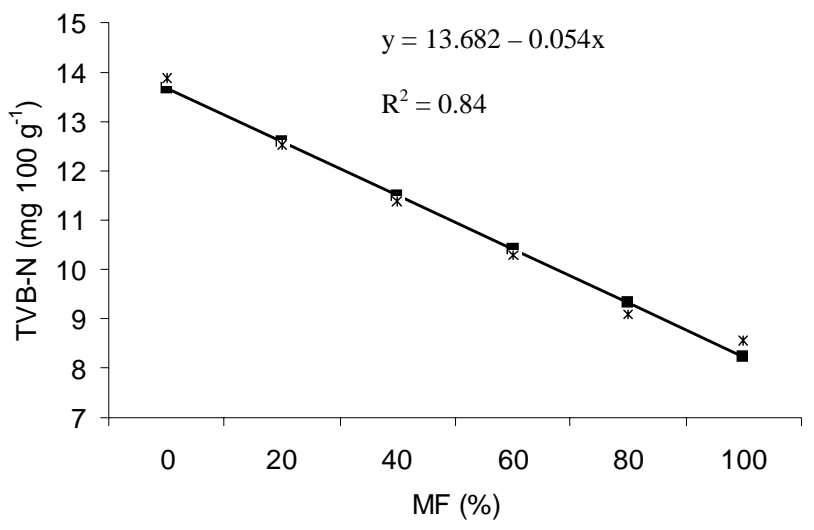

Figure 2 - Mean total volatile nitrogenous bases (TVB-N) in sausages prepared with inclusion levels of minced fish (MF) from Nile tilapia filleting waste and stored for 40 days at $0 \pm 0.3^{\circ} \mathrm{C}$. which had a yellowish color. On the other hand, sausages prepared with higher percentages of MF highlighted the darker color of MF in relation to the isolated soy protein. Desmond and Kenny (1998) also reported a decrease in the $b^{*}$ values with the inclusion of $0 \%$ (11.4) to $15 \%(10.4)$ of bovine-heart surimi in sausages.

The $\mathrm{pH}$ values of sausages did not vary $(p>0.05)$ between treatments, but decreased in a quadratic way $(p<0.05)$ during the storage, from 6.48 (day 5) to 6.27 (day 40) (Figure 4). Decreases in $\mathrm{pH}$ during refrigerated storage were also reported for sausages prepared with MF from Japanese threadfin bream, (Raju et al., 2003),
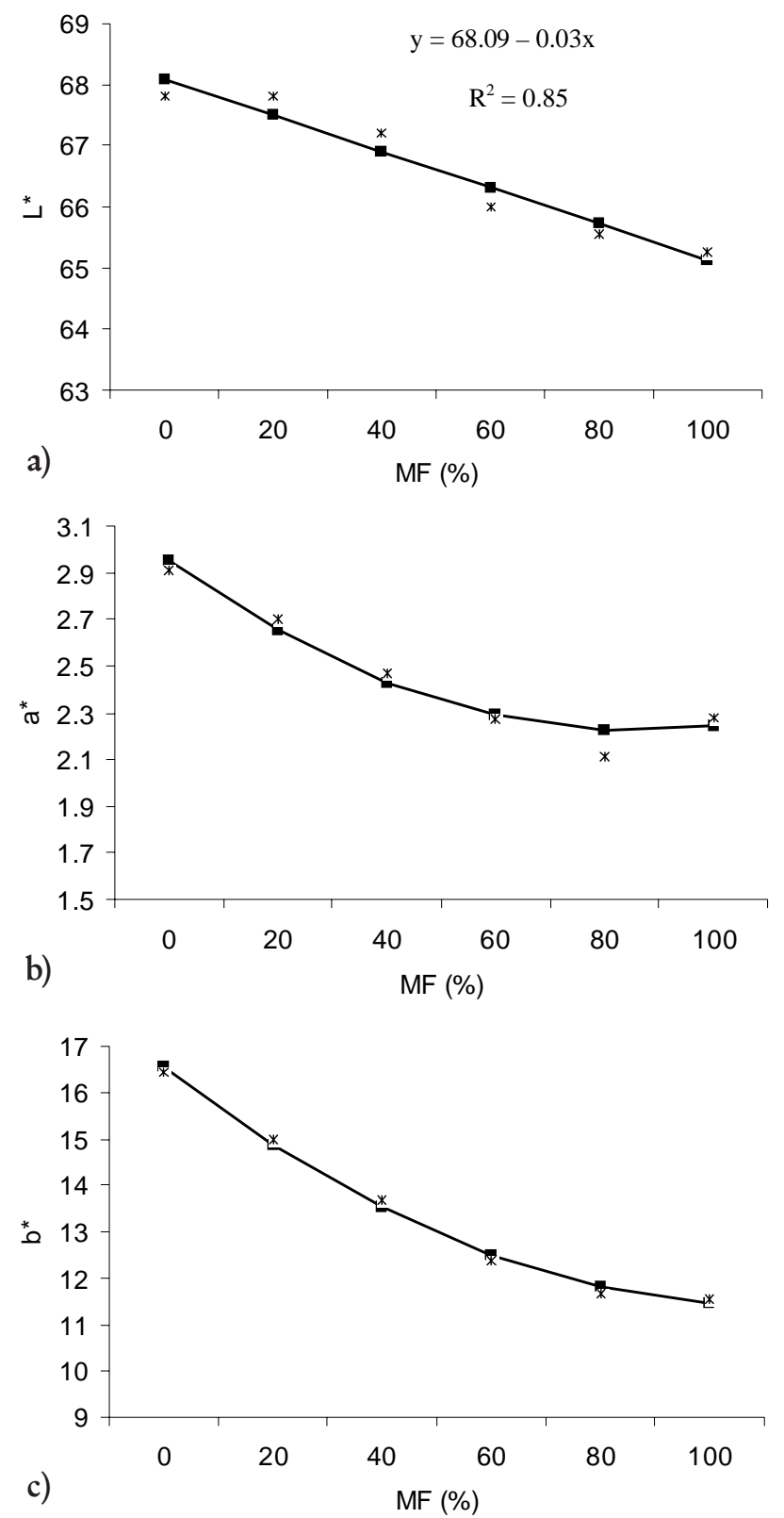

Figure 3 - Average L* (a), a* (b) and b* (c) values for sausages prepared with inclusion levels of minced fish (MF) from Nile tilapia filleting waste and stored for 40 days at $\mathrm{O} \pm 0.3^{\circ} \mathrm{C}$. 
chicken (Horng et al., 2002) and beef (Candogan and Kolsarici, 2003). This phenomenon may be associated with the acidification of the medium by lactic bacteria, psychrotrophic microrganisms resistant to nitrite action and competitors of the pathogenic bacteria, ordinarily found in vacuum-packed meat products stored under refrigeration (Franz and Holy, 1996).

Pathogenic microorganisms (Staphylococcus aureus and Salmonella $s p$ ) were not detected and the population of total coliforms in the sausages, evaluated by the Most Probable Number method (MPN), was $<3 \mathrm{MPN} \mathrm{g}^{-1}$ sample at both the initial (day 5) and final point (day 40). The aerobic psychrotrophic bacteria present in the sausages showed a fairly pronounced multiplication after $40 \mathrm{~d}$ of storage (Table 1). In sausages elaborated with MF from sardine (Ravishankar et al., 1992), Japanese threadfin bream (Raju et al., 2003) and a mixture of sardine Sardinops sagax and mullet Mugil cephalus (Rado and Oba, 1984), an increase in the aerobic psychrotrophic bacterial count was also observed during 26, 30 and 36

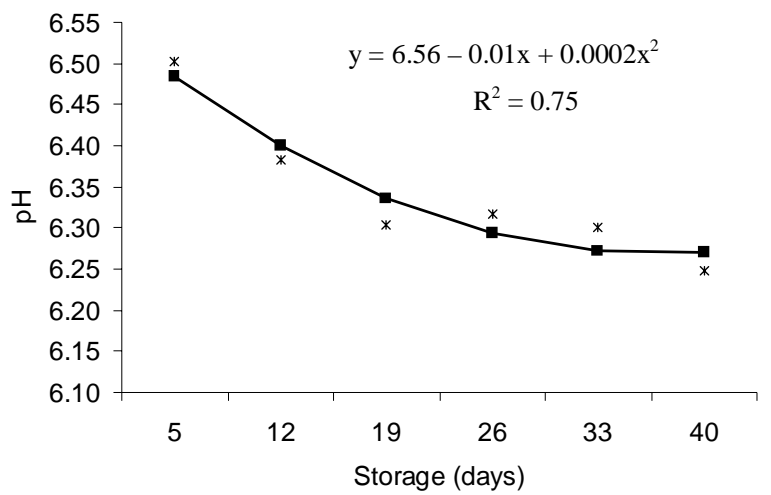

Figure 4 - Mean $\mathrm{pH}$ values in sausages prepared with inclusion levels of minced fish (MF) from Nile tilapia filleting waste and stored for 40 days at $0 \pm 0.3^{\circ} \mathrm{C}$. days of storage at 2,6 and $5^{\circ} \mathrm{C}$, respectively. No logical trend for the multiplication of this type of bacteria was detected, and it ranged from $3.4 \times 10^{5}$ to $6.0 \times 10^{7} \mathrm{CFU}$ $\mathrm{g}^{-1}$. In a study with levels of inclusion of mechanically separated layer hen meat in mortadella sausage, no differences were also observed regarding counts of aerobic psychrotrophic bacteria (Trindade et al., 2005). In accordance with the standards established by the Brazilian legislation (Brasil, 1997), fresh fish may have the following limits for bacterial contamination: fecal coliforms, maximum of $10^{2} \mathrm{NMP} \mathrm{g}^{-1}$; Staphylococcus aureus, maximum of $10^{3} \mathrm{CFU} \mathrm{g}^{-1}$; Salmonella, absence in $25 \mathrm{~g}$ sample, with no limits for total coliforms and the total count aerobic psychrotrophic bacterial count. Therefore, all the sausages remained within limits established by this legislation during the 40-day storage.

For sensory attributes of flavor, texture, odor and overall acceptability, only principal effects for MF were detected. However, an interaction between MF and storage was detected for sensory attribute color.

Table 1 - Total Count of aerobic psychrotrophic bacteria of sausages prepared with inclusion levels of minced fish (MF) from Nile tilapia filleting waste after 40 days of storage at $0 \pm 0.3^{\circ} \mathrm{C}$.

\begin{tabular}{ccc}
\hline \multirow{2}{*}{ Treatments $(\% \mathrm{MF})$} & \multicolumn{2}{c}{ Days of storage } \\
\cline { 2 - 3 } & \multicolumn{2}{c}{$\mathrm{CFU} \mathrm{g}^{-1}$} \\
\hline 0 & $<10^{2}$ & $3.4 \times 10^{5}$ \\
20 & $<10^{2}$ & $2.1 \times 10^{6}$ \\
40 & $<10^{2}$ & $1.9 \times 10^{5}$ \\
60 & $<10^{2}$ & $4.3 \times 10^{6}$ \\
80 & $<10^{2}$ & $6.0 \times 10^{7}$ \\
100 & $<10^{2}$ & $3.1 \times 10^{6}$ \\
\hline
\end{tabular}

Table 2 - Product-moment Pearson correlation coefficients $(r)$ between $\mathrm{pH}$ values, total volatile bases nitrogenous (TVB$\mathrm{N}$ ), instrumental color ( $\mathrm{L} * \mathrm{a}$ * and $\mathrm{b} *$ ), lipid oxidation (TBARS) and sensory evaluation (color, flavor, texture, odor and overall acceptability) of sausages prepared with inclusion levels of minced fish (MF) from Nile tilapia stored at $0 \pm 0.3^{\circ} \mathrm{C}$ for 40 days.

\begin{tabular}{|c|c|c|c|c|c|c|c|c|c|c|c|}
\hline & $\mathrm{n}$ & TVP & Inst & nental & & TPAPS & & & ory evalu & & \\
\hline & pr & $1 \times D-1 V$ & $L^{*}$ & $a^{*}$ & $b *$ & 1DAKS & Color & Odor & Texture & Flavor & Overall \\
\hline $\mathrm{pH}$ & 1.00 & & & & & & & & & & \\
\hline TVB-N & -0.46 & 1.00 & & & & & & & & & \\
\hline $\mathrm{L}^{*}$ & 0.34 & -0.02 & 1.00 & & & & & & & & \\
\hline$a^{*}$ & -0.60 & 0.72 & -0.10 & 1.00 & & & & & & & \\
\hline$b^{*}$ & -0.17 & 0.75 & 0.50 & 0.63 & 1.00 & & & & & & \\
\hline TBARS & -0.15 & -0.10 & -0.76 & -0.16 & -0.55 & 1.00 & & & & & \\
\hline Color & -0.22 & 0.63 & 0.67 & 0.43 & 0.78 & -0.63 & 1.00 & & & & \\
\hline Odor & 0.04 & -0.53 & -0.05 & -0.37 & -0.52 & 0.15 & -0.34 & 1.00 & & & \\
\hline Texture & 0.17 & -0.43 & 0.07 & -0.43 & -0.43 & -0.11 & -0.06 & 0.47 & 1.00 & & \\
\hline Flavor & 0.11 & -0.30 & -0.05 & -0.40 & -0.50 & 0.06 & -0.07 & 0.50 & 0.81 & 1.00 & \\
\hline Overall & 0.11 & -0.32 & 0.14 & -0.39 & -0.35 & -0.17 & 0.09 & 0.47 & 0.95 & 0.89 & 1.00 \\
\hline
\end{tabular}


The sensory acceptability by panelists did not vary $(p>0.05)$ during the 40 day storage period regarding all sensory attributes. This is regarded a positive aspect, because a variation in the sensory characteristics during the shelf-life is reflected in the rejection by the panelists, who detect changes in the sensory attributes, mainly caused by the development of deteriorating bacteria and oxidation of lipids (Bloukas et al., 1999). In contrast, a decrease in overall acceptability from eight (8) to four (4) on a 9-point hedonic scale, of sausages prepared with MF from sardine was observed during refrigerated storage $\left(2^{\circ} \mathrm{C}\right)$ for 26 days by Ravishankar et al. (1992). Sausage prepared with MF from Japanese threadfin bream also presented a decrease in the scores for the attributes of color (9 to 6), texture (8 to 6), flavor (8 to 6 ) and overall acceptability

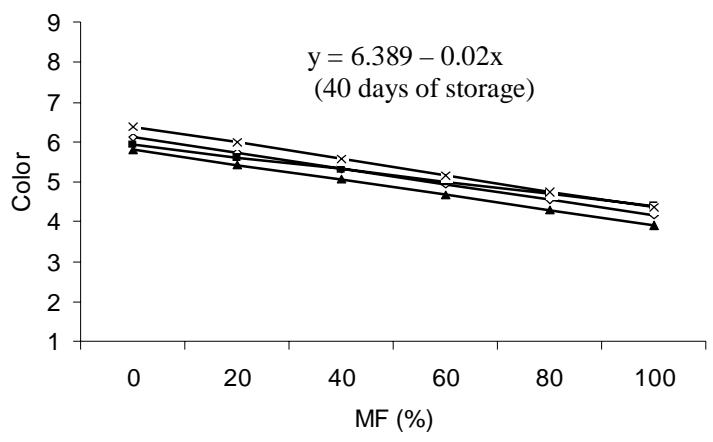

a) $\rightarrow-\infty$ days $\rightarrow 19$ days $\leftarrow 33$ days $-x-40$ days
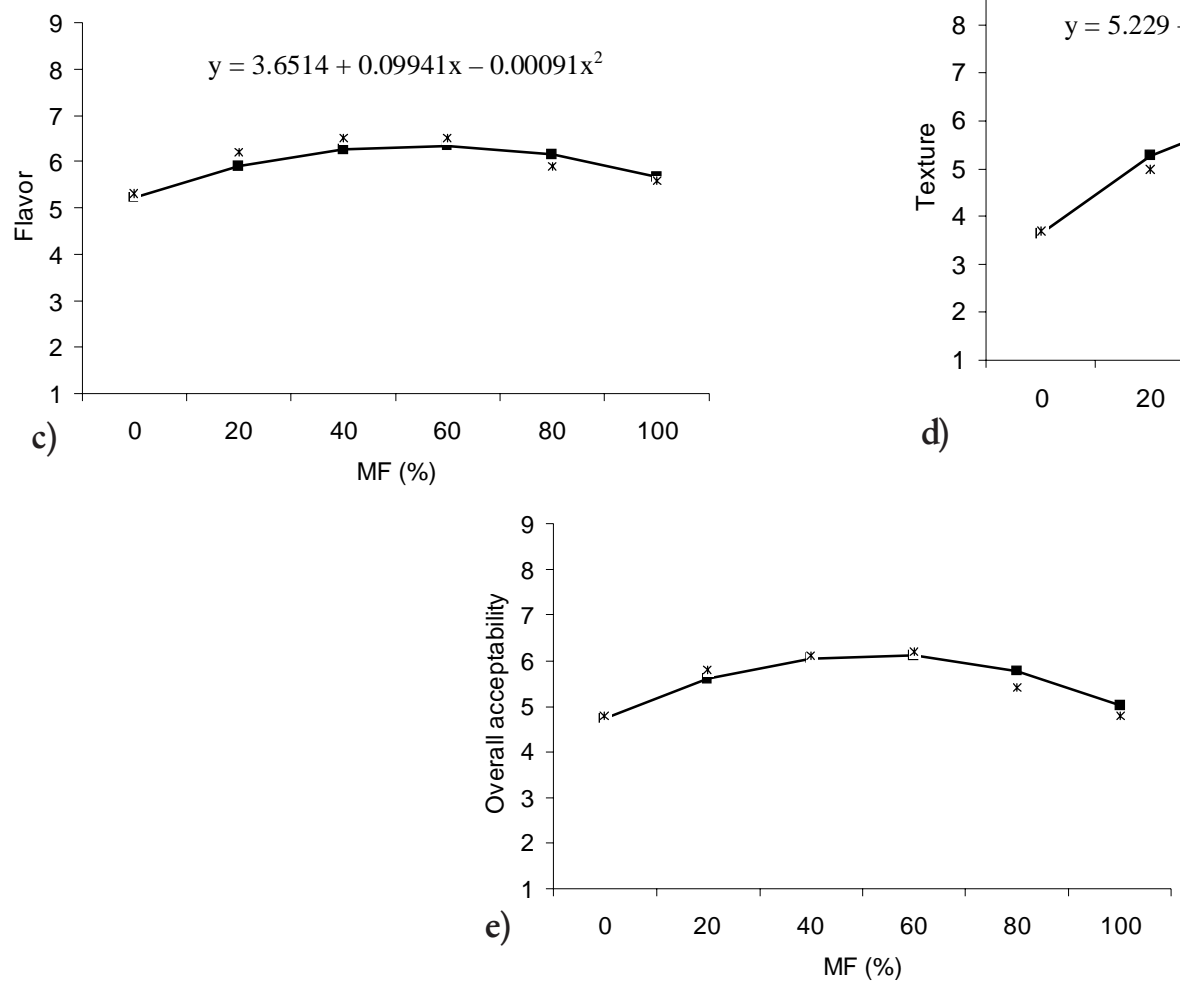

Figure 5 - Mean scores in the sensory evaluation for color (a), odor (b), texture (c) flavor (d) and overall acceptability (e) of sausages prepared with inclusion levels of minced fish (MF) from tilapia filleting waste stored at $0 \pm 0.3^{\circ} \mathrm{C}$ for 40 days.
(8 to 6) on a 9-point hedonic scale during refrigerated storage $\left(6^{\circ} \mathrm{C}\right)$ for 30 days, as reported by Raju et al. (2003).

Acceptability of the sensory attributes of color, flavor, texture, odor and overall acceptability of the sausage differed $(p<0.05)$ - Figure 5 . Scores for the sensory attribute of color decreased from 6.4, "liked slightly", in sausages prepared without the addition of MF, to 4.4, "disliked slightly, in sausages prepared with $100 \%$ MF (Figure 5a). The sensory color of the sausages showed a positive correlation with the $\mathrm{b}$ * values $(r=0.78, p<0.001)$ (Table 2), i.e., the best results for color were registered for more yellowish sausages, i.e., those with the lowest amounts of MF. The scores relating to the odor of the sausages showed a linear increase $(p<0.05)$ with the addition of MF, from
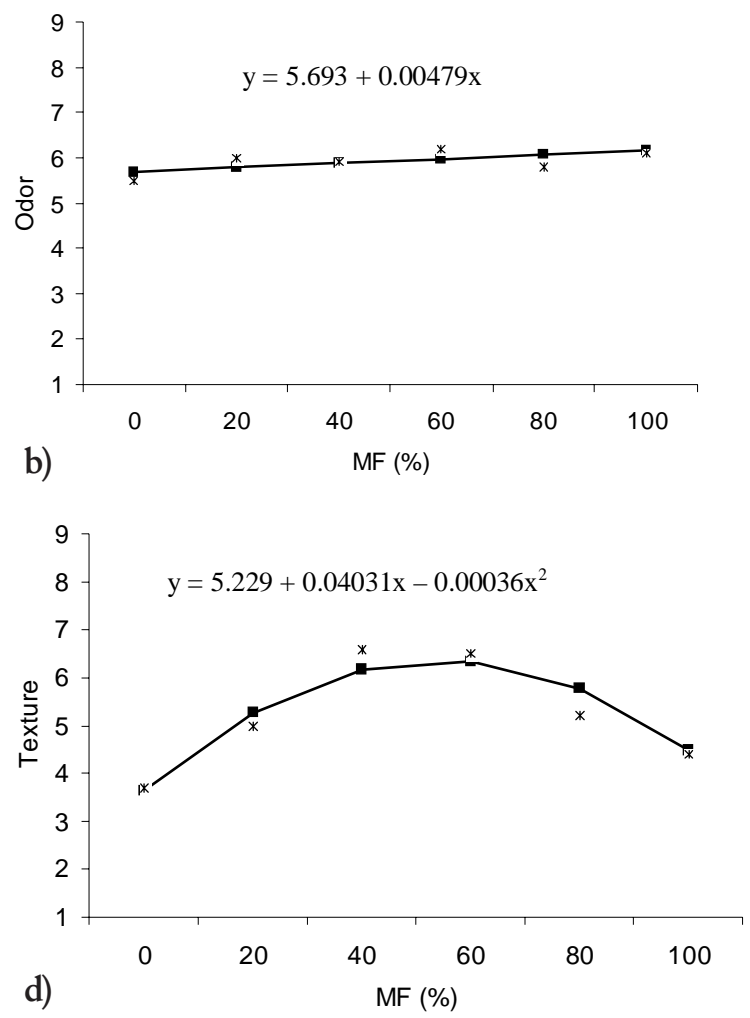
5.7 ("neither liked / nor disliked") at $0 \% \mathrm{MF}$, to 6.2 ("liked slightly") at $100 \%$ of MF (Figure 5b). This could be explained by the preference of the panelists for a strong fish odor in sausages prepared with higher percentages of MF, probably as a result of the higher lipid contents.

The scores for the attribute of texture of the sausages showed a quadratic variation $(p<0.05)$ with the addition of MF (Figure 5d). The maximum score for this attribute was registered at $54.6 \%$ of MF inclusion, in other words, between treatments with 40 and $60 \%$ MF (6.2 and 6.3 - "liked slightly"). Sausages from treatments without the addition of MF were evaluated as quite "chewy" by many panelists, receiving therefore low scores (3.7 - "disliked moderately"). However, panelists regarded sausages prepared with $100 \% \mathrm{MF}$ as having excessive tenderness, yielding a 4.5 score ("disliked slightly"). Daros et al. (2005) also reported the texture of the sausages as increasingly softer with increasing contents of mechanically deboned poultry meat (from 0 to $100 \%)$.

The flavor of the sausages had a quadratic variation $(p<0.05)$ with increasing inclusion of MF (Figure 5c). The maximum score for this attribute was registered at 55.9\% MF inclusion, i.e., between treatments with 40\% (6.3 - "liked slightly") and 60\% MF (6.4 - "liked slightly). Sausages regarded as least tasty were those formulated without the addition of MF (5.2 - "neither liked / nor disliked"), reported as having a weak fish flavor. This may have occurred because the tilapia fillet is a mild flavored, low fat fisheries product. Sausages elaborated with 100\% of MF (5.7 - "neither liked / nor disliked"), were regarded by many panelists as having a too-strong fish flavor.

The overall acceptability of the sausages presented a quadratic variation $(p<0.05)$ with the inclusion of MF (Figure 5e). The maximum score for this attribute was registered at $52.9 \% \mathrm{MF}$ inclusion, including treatments with the addition of 40 and $60 \%$ of MF (6.1 - "liked slightly"). The least accepted sausages were those formulated with $0 \%$ of MF (4.7 - "disliked slightly") and $100 \%$ of MF (5.0 - "neither liked nor disliked). The overall acceptability of the sausages was positively correlated with texture $(\mathrm{r}=0.95, p<0.001)$ and flavor $(\mathrm{r}=0.89, p$ $<0.001$ ) (Table 2), indicating that the higher the scores for texture and flavor, the better the overall acceptability. The treatment showing the highest overall acceptability $(60 \% \mathrm{MF})$ was in accordance with the Brazilian legislation (Brasil, 2000), which limits addition of MF to $60 \%$ in regular sausages.

\section{Acknowledgements}

To CNPq for funding the project (Process $\mathrm{N}^{\circ}$ 55.1652/2005-5) and for the granting of the scholarship to the first author. We also thank the "Tilapia do Brasil" company for the donation of the tilapia filleting wastes used in the experiment.

\section{References}

American Public Health Association [APHA]. 1992. Compendium of Methods for the Microbiological Examination of Foods. 3ed. APHA, Washington, DC, USA.

Bloukas, J.G.; Arvanitoyannis, I.S.; Siopi, A.A. 1999. Effect of natural colourants and nitrites on colour attributes of frankfurters. Meat Science 52: 257-265.

Brasil. Instruction $\mathrm{n}^{\circ}$ 4, March 31, 2000 Secretariat of Agricultural Protection of Ministry of Agriculture and Supply. Approves the Technical Regulations and Identity Quality of Mechanically Deboned Meat of Mortadella, Sausages and Frankfurter-type sausages. Official Gazette of the Federative Republic of Brazil, Brasília, DF, 05 April 2000 Section 1, page 610 (in Portuguese).

Brasil. Ordinance No. 451 of 19 September 1997. Ministry of Health. Division of the National Health Surveillance of Food. National Secretariat of Health Surveillance, 1997 (in Portuguese).

Candogan, K.; Kolsarici, N. 2003. Storage stability of low-fat beef frankfurters formulated with carrageenan or carrageenan with pectin. Meat Science 64: 207-214.

Contreras-Guzmán, E.S. 2002. Biochemistry of Fish and Invertebrates. Cecta-Usach Press, Santiago, Chile (in Spanish).

Daley, L.H.; Deng, J.C.; Oblinger, J.L. 1979. Stability of refrigerated mullet sausage. Journal of Food Science 44: 883-891.

Daros, F.G.; Masson, M.L.; Amico, S.C. 2005. The influence of the addition of mechanically deboned poultry meat on the rheological properties of sausage. Journal of Food Engineering 68: 185-189.

Desmond, E.M.; Kenny, T.A. 1998. Preparation of Surimi-like extract from beef hearts and its utilization in frankfurters. Meat Science 50: 81-89.

Estévez, M.; Ventanas, S.; Cava, R. 2007. Oxidation of lipids and proteins in frankfurters with different fatty acid compositions and tocopherol and phenolic contents. Food Chemistry 100: 55-63.

Franz, C.M.A.P.; Holy, A.V. 1996. Bacterial populations associated with pasteurized vacuum-packed Vienna sausages. Food Microbiology 13: 165-174.

Garcia, F.T.; Gagleazzi, U.A.; Sobral, P.J.A. 2000. Variation of the physical and chemical properties of Italian type salami during dehydration and fermentation. Brazilian Journal of Food Technology 3: 151-158 (in Portuguese, with abstract in English).

Garduño-Lugo, M.; Granados-Alvarez, I.; Olivera-Novoa, M.; Muñoz-Córdova, G. 2003. Comparison of growth, fillet yield and proximate composition between Stirling Nile tilapia (wild type) (Oreochromis niloticus, Linnaeus) and red hybrid tilapia (Florida red tilapia X Stirling red O. Niloticus) males. Aquaculture Research 34: 1023-1028.

Gray, J.I.; Gomaa, E.A.; Buclkey, D.J. 1996. Oxidative quality and shelf life of meats. Meat Science 43: 111-123.

Horng, L.J.; Hui, L.Y.; Chin, K.C. 2002. Effect of dietary fish oil on fatty acid composition, lipid oxidation and sensory property of chicken frankfurters during storage. Meat Science 60: 161167.

Howgate, P. 1976. Determination of Ttotal Volatile Bases. Torry Research Station, Aberdeen, UK.

Hu, Y.; Xia, W.; Ge, C. 2008. Characterization of fermented silver carp sausages inoculated with mixed starter culture. LWT Food Science and Technology 41: 730-738.

Kelleher, S.D.; Silva, L.A.; Hultin, H.O.; Wilhelm, K.A. 1992. Inhibition of lipid oxidation during processing of washed, minced Atlantic mackerel. Journal of Food Science 57: 1103-1108.

Kristbergsson, K.; Arason, S. 2007. Utilization of by-products in the fish industry. p.233-258. In: Oreopoulou, V.; Russ, W., eds. Utilization of by-products and treatment of waste in the food industry. Springer, New York, NY, USA

López-Caballero, M.E.; Guillén, M.C.; Mateos, M.P.; Montero, P.A 2005. Functional chitosan-enriched fish sausage treated by high pressure. Journal of Food Science 70: 166-171. 
Meilgaard, M.; Civille, G.V.; Carr, B.T. 1999. Sensory evaluation techniques. 3ed. CRC Press, New York, NY, USA.

Murphy, S.C.; Gilroy, D.; Kerry, J.F.; Buckley, D.J.; Kerry, J.P. 2004. Evaluation of surimi, fat and water content in a low/no added pork sausage formulation using response surface methodology. Meat Science 66: 689-701.

Olivo, R. 2006. Oxidative changes in meat products. p.155-163. In: Shimokomaki, M.; Olivo, R.; Terra, N.N.; Franco, B.D.G.M., eds. News in meat science and technology. Varela, São Paulo, SP, Brazil.

Panpipat, W.; Yongsawatdigul, J. 2008. Stability of potassium iodide and omega-3 fatty acids in fortified freshwater fish emulsion sausage. LWT - Food Science and Technology 41: 483-492.

Park, E.Y.; Brekke, C.J.; Branen, A.L. 1978. Use of pacific hake (Merluccius productus) in a frankfurter formulation. Journal of Food Science 43: 1637-1645.

Rado, E.; Oba, R.S. 1984. Microbiological aspects of fish sausage stored at $5^{\circ}, 20^{\circ}$ and $30^{\circ} \mathrm{C}$. Boletín de Investigación del Instituto Tecnológico Pesquero del Peru 2: 89-95.

Raju, C.V.; Shamasundar, B.A.; Udupa, K.S. 2003. The use of nisin as a preservative in fish sausage stored at ambient $\left(28 \pm 2^{\circ} \mathrm{C}\right)$ and refrigerated $\left(6 \pm 2^{\circ} \mathrm{C}\right)$ temperatures. International Journal of Food Science and Technology 38: 171-185.

Ravishankar, C.N.; Setty, T.M.R.; Shetty, T.S. 1992. Method for the preparation of sausages of acceptable quality from Indian oil sardine (Sardinella longiceps) and their shelf-life at different storage temperatures. Food Control 3: 144-148.

Statistical Analysis Systems [SAS]. 2002. SAS User's Guide Basics; Version 9.1.3 Cary, NC, USA.
Sini, T.K.; Santhosh, S.; Joseph, A.C.; Ravisankar, C.N. 2008 Changes in the characteristics of rohu fish (Labeo rohita) sausage during storage at different temperatures. Journal of Food Processing and Preservation 32: 429-442.

Summo, C.; Caponio, F.; Pasqualone, A. 2006. Effect of vacuumpackaging storage on the quality level of ripened sausages. Meat Science 74: 249-254.

Szenttamásy, E.R.; Barbosa, S.M.V.B.; Oetterer, M.; Moreno, I.A.M. 1993. Freshwater fish technology: utilization of "pacu" (Piaractus mesopotamicus). Scientia Agricola 50: 303-310 (in Portuguese, with abstract in English).

Tenuta-Filho, A.; Jesus, R.S. 2003. Aspects of the utilization of minced fish as industrial raw material. Ciência e Tecnologia de Alimentos 37: 59-64 (in Portuguese, with abstract in English).

Trindade, M.A.; Contreras, C.C.; Felício, P.E. 2005. Mortadella sausage formulations with partial and total replacement of beef and pork backfat with mechanically separated meat from spent layer hens. Journal of Food Science 70: 236-241.

Uyhara, C.N.S.; Oliveira Filho, P.R.C.; Trindade, M.A.; Viegas, E.M.M. 2008. Addition of pigments to Nile tilapia frankfurters: effect on sensory acceptance. Brazilian Journal of Food Technology 11: 271-278 (in Portuguese, with abstract in English).

Vyncke, W. 1970. Direct determination of the thiobarbituric acid value in trichloroacetic extracts of fish as a measure of oxidative rancidity. Fette-Seinfen Anstrichmittel 72: 1084-1087.

Received April 03, 2009

Accepted November 18, 2009 